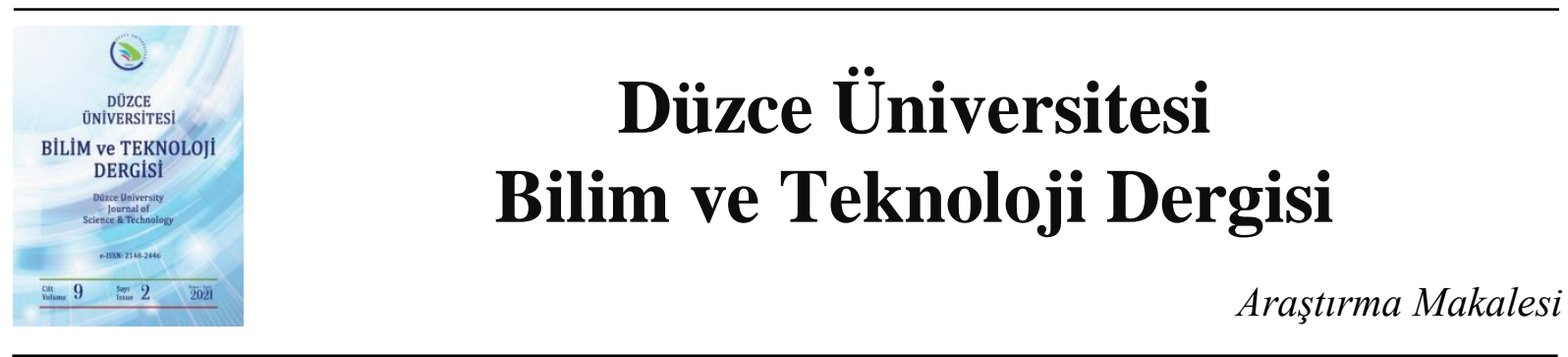

\section{İstanbul Kent Ormanında Arazi Kullanım Yoğunluğuna Bağl1 Toprak Özelliklerinin Değişimi}

\author{
(D) Murat SARGINCI ${ }^{\text {a,* }}$, D Zeynep Bengisu YEŞIL ${ }^{a}$, (D)Abdullah Hüseyin DÖNMEZ ${ }^{\mathrm{a}}$, (D Oktay \\ YILDIZ $^{\mathrm{a}}$, \\ ${ }^{a}$ Orman Mühendisliği Bölümü, Orman Fakültesi, Düzce Üniversitesi, Düzce, TÜRKIYYE \\ * Sorumlu yazarin e-posta adresi: muratsarginci@duzce.edu.tr \\ DOI:10.29130/dubited.816418
}

\begin{abstract}
ÖZET
$\mathrm{Bu}$ çalışmada rekreasyon alanlarında orman toprağının farklı kullanım koşullarına bağlı fiziksel ve kimyasal özelliklerindeki değişim araştırılmıştır. Bu kapsamda İstanbul Hekimbaşı Kent Ormanı içerisinde bulunan farklı kullanım şekillerinin olduğu alanlardan iki farklı toprak derinliğinde toprak örneklemesi ve toprak yüzeyinden ölü örtü örneklemesi yapılmıştır. Sahadaki yoğun kullanıma bağlı olarak toprak hacim ağırlığı, iskelet miktarı, toprak reaksiyonu $(\mathrm{pH})$ ve kum oranının arttığı, topraktaki inorganik karbon (IOC), organik karbon (OC), organik madde $(\mathrm{OM})$, azot $(\mathrm{N})$ oranları ve hektardaki toplam miktarları ile birlikte katyon değişim kapasitesinin (KDK) ve ölü örtü miktarının azaldığı tespit edilmiştir. Sonuç olarak insan kullanımının daha yoğun olduğu alanlarda toprağın verimliliği ve sürdürülebilirliği üzerinde olumsuz etkilere neden olduğu belirlenmiştir. Bu etkilerin en aza indirilmesi için alanın taşıma kapasitesinin toprak özelliklerine en az düzeyde zarar verecek şekilde planlanması gerekmektedir. İnsanların tam alan yerine sahadaki belirli noktaları kullanması, yürüyüş yolları dışındaki alanlara insan girişlerinin azaltılması en başta alınacak önlemler olarak düşünülmektedir.
\end{abstract}

Anahtar Kelimeler:Saha taşıma kapasitesi, Sürdürülebilirlik, Rekreasyon

\section{Changes of Soil Properties Due to Land Use Intensity in Istanbul Urban Forest}

\begin{abstract}
In this study, changes in physical and chemical properties of forest soil due to different usage conditions in recreation areas is investigated. In this context, soil sampling at two different depths of soil and litter sampling from the soil surface from areas with different uses in the Istanbul Hekimbaşı Urban Forest were made. It was determined that soil bulk density, stoniness amount, soil reaction $(\mathrm{pH})$ and sand ratio were increased and inorganic carbon (IOC), organic carbon $(\mathrm{OC})$, organic matter $(\mathrm{OM})$, nitrogen $(\mathrm{N})$ ratios and total amounts per hectare, cation exchange capacity (CEC) and the amount of litter were decreased in more intensively used areas. As a result, it has been determined that it causes negative effects on the fertility and sustainability of the soil in areas where human use is more intense. In order to minimize these effects, the carrying capacity of the area should be planned in a way that will cause the least damage to the soil properties. It is considered as the first measures tobe taken by people is using certain points on the field instead of the full area, and reducing human entry to areas other than walkways.
\end{abstract}

Keywords: Field carrying capacity, Sustainability, Recreation

Geliş: 26/10/2020, Düzeltme: 15/01/2021, Kabul: 22/01/2021 


\section{GIRIS}

Orman ekosistemleri gibi doğal alanlar hassas dengeler ve farklı dengelerin etkileşiminden meydana gelen karmaşık sistemler bütünüdür. Toprak ise bu ekosistemlerin kesişim noktasını oluşturan, kendi içerisinde birçok sistemi barındıran, ayrıca çoğu sistemin de temelini oluşturan önemli bir yapıdır [1]. Toprak, onunla etkileşime geçen sistemlerden etkilenip, fiziksel ve kimyasal özelliklerinde değişimler göstermektedir. Toprak yüzeyinde bulunan ölü örtü ise su tutma kapasitesini, besin elementi oranı, katyon değişim kapasitesini arttırması gibi toprağa olumlu birçok etkinin merkezinde yer almaktadır [2]. Rekreasyonel faaliyetler her ne kadar çevre bilincinin artması, doğa bilincinin ve korumasının desteklenmesi gibi olumlu etkiler oluştursa da, toprak sıkışması başta olmak üzere, besin kaybı, organik madde kaybı, bitki örtüsünün zarar görmesi, alan kayb1, alan kirliliği gibi istenmeyen olumsuz etkilere de yol açabilmektedir [3]. Nitekim Avrupa Birliği ülkelerinde toprak sıkışması, toprak koruma bakımından öncelikli araştırma alanı olarak gösterilmektedir [4]. Toprak hacim ağırlığının artması, gözenekliliğinin azalması, hidrolik iletkenlik ve havalanmasının değişmesi ve buna bağlı bitki köklerinin ilerlemesini engelleyici mekanik bir direncin oluşması toprak sıkışmasını önemli kılan nedenlerin başında gelmektedir. Ayrıca ortaya çıkan bu olumsuz durum bitki büyümesini de kötü yönde etkilemektedir[5]. Toprak horizonlarında sıkışma problemi başladığı andan itibaren kök büyümesi mekanik bir dirençle karşılaşmakta, su ve besin elementlerinin alımı engellenmekte ve bitkisel üretkenlik düşmektedir [6-8]. Yoğun insan faaliyetleri başta geçiş ekosistemleri ile kırılgan ekosistemlerin bulunduğu sahalarda olmak üzere [9], rekreasyon alanlarının da dahil olduğu birçok ekosistem degeri kazanımı çok zor olan zararlara neden olmaktadır [10].

Doğal peyzaj çeşitliliği, bitki ve yaban hayatı zenginliği, gibi özellikleriyle doğal alanlar kent insanları için cazip rekreasyon alanları haline gelmiştir[11]. Rekreasyon alanlarında yürütülen faaliyetler farklılık gösterse de toprak üzerinde oluşturabileceği olumsuz etkiler benzerdir. $\mathrm{Bu}$ etkilerin yoğunluğu arttıkça zamanla toprak sıkışması meydana gelmekte ve buna paralel olarak toprağın birçok fiziksel ve kimyasal özelliği bitki yetișmesi açısından kötüye gitmektedir [3,10,12]. Tüm bu olumsuzluklar toprak üzerinde yetișen bitkilerin boylarında kısalmaya, biokütlesinde azalmaya, tür kompozisyonunda değişikliğe, toprak yüzeyinde artan erozyona paralel olarak köklerin açığa çıkmasına, bitki patojenlerinin yayılmasına ve ekosistem için daha birçok olumsuz koşulların ortaya ç1kmasına yol açabilmektedir [13].

Hızla artan dünya nüfusu doğada yapılan rekreasyonel faaliyetlere katılımında artmasına neden olmaktadır. Bu durum bugün olduğu gibi, gelecekte de büyük kitleler halinde devam edecektir. Doğal ekosistemlerin bu kullanımdan olumsuz etkilendiği de bilinen bir gerçektir [14]. Bu ekosistemler üzerinde artan yoğun insan baskısından kaynaklı ekolojik koşulların değişimi ve bu ekosistemlerde oluşan tahribin restorasyonu konusunda çalışmaların yapılması büyük önem taşımaktadır. Özellikle restorasyon çalışmalarında değişen ekolojik koşullara paralel olarak tercih edilen yeni ağaç türlerinin sahalara uyumunun araştırılması ve ayrıca bu türlerin yetişme ortamında yarattı̆g 1 değişimlerin belirlenmesi ekolojik açıdan önemle ele alınması gereken konulardır $[9,10,15]$.

İnsan faaliyetlerine açık doğal alanlarda yöneticilerin karşılaştığı en büyük sorunların başında koruma ve kullanma dengesinin sağlanması gelmektedir [16]. İnsan nüfusunun hızlı artışına paralel olarak artan rekreasyonel talepler koruma ve kullanma dengesinin gözetilmesinde, bu iki zit görevin bir arada yürütülmesinde zorluklar ortaya çıkarmaktadır [17]. Aynı bölgede bulunan nispeten ekolojik özellikleri korunmuş alanlar ile özellikle yoğun insan baskısı sonucu tahribe uğramış, değişmiş ya da dönüştürülmüş alanlarda eşzamanlı olarak yapılacak bilimsel çalışmalar ve bu çalışmaların sonuçlarının karşılaştııılması meydana gelen etkilerin ortaya konmasında faydalı olacaktır.

Dolayısıyla bu çalışmada ülkemiz insan nüfusunun en fazla yoğunluğa ulaştığı il olan İstanbul'da, rekreasyon fonksiyonu ile ön plana çıkan Anadolu yakasında bulunan Beykoz Hekimbaşı Kent Ormanı sınırlarında, yoğun insan faaliyetlerine açık alanlar (piknik alanları, yürüyüş yolları) ile nispeten insan giriş̧ çıkışının daha az yoğun olduğu alanlardaki toprak özelliklerinin karşılaştırılması amaçlanmıştır. Özellikle yoğunluğun fazla olduğu alanlarda başta toprak sıkışması ve toprak organik 
maddesinin azaltılacağı düşünülerek bu etkileri azaltıcı ne gibi tedbirlerin alınması gerektiği tartışılmıştır.

\section{MATERYAL VE YÖNTEM}

\section{A. ÇALIŞMA ALANI}

Çalışma alanı İstanbul iline bağlı Beykoz ilçesi sınırlarında bulunan Hekimbaşı mevkiindeki Kent Ormanı içerisinde yer almaktadır ( $41^{\circ} 03^{\prime} 43^{\prime \prime} \mathrm{N}-29^{\circ} 06^{\prime} 32^{\prime \prime}$ E). Ayrıca alan Elmalı Barajı çevresinde Kuzeyde Beykoz ilçesi, Güneyde ve Doğuda Ümraniye, Batıda Üsküdar ilçe sınırları ile çevrilidir. İçerisinden Asya'yı Avrupa'ya bağlayan Fatih Sultan Mehmet Köprüsünün ana arteri olan yollar geçmektedir. Çevresindeki Kadıköy, Maltepe, Üsküdar, Ümraniye, Beykoz ve Çekmeköy ilçeleri başta olmak üzere yerleşim yerlerinde, yaklaşık beş milyon insan yaşamaktadır. Kent Ormanı içerisinde bulunan ormanlar genellikle ağaçlandırma (plantasyon) yöntemi ile oluşturulmuş ormanlardır. Elmalı Baraj Gölü kent ormanının ortasında olması nedeniyle çok yüksek bir kaynak değer oluşturmaktadır. Kent ormanını oluşturan mevcut tesisler; ana giriş kapısı, kontrol kulübesi, tuvaletler, 900 araçlık otopark, gözlem kulesi, enformasyon binası, 7 km'lik orman yolu, 12 km'lik yangın emniyet şeritleri, yaklaşı $10 \mathrm{~km}$ ihata tesisidir [18].Verilerin amaca yönelik karşılaştırılabilir olması için birbirine yakın alanlarda Şekil 1'de gösterilen kullanım türüne bağlı noktalı alanlardan örneklemeler gerçekleştirilmiştir. Buna göre patika, mesçere içi açıklık, meşçere ve rekreasyon alanları olmak üzere toplam 4 farklı kullanım alanı belirlenmiştir. Burada patika saha içi yürüyüş yollarını, meşçere içi açıklık sahada ağaçlık alanlar içerisinde kapalılığın kırılarak açıklık oluşan çalı ve otsu alanları, meşçere sahada kapalılık oluşturan ağaçlık alanları ve rekreasyon da saha içerisinde masa vb. yerleştirilerek insanların oturma ya da piknik vb. faaliyetlerini gerçekleştirebileceği yerleri temsil etmektedir. Sahanın fiziksel durumu göz önünde bulundurularak kullanım yoğunluğu bakımından patika yol en yoğun, rekreasyon (piknik) alanları yoğun ve meşçere ile meşçere içi açıklık alanlar az yoğun alan olarak kabul edilmiştir.

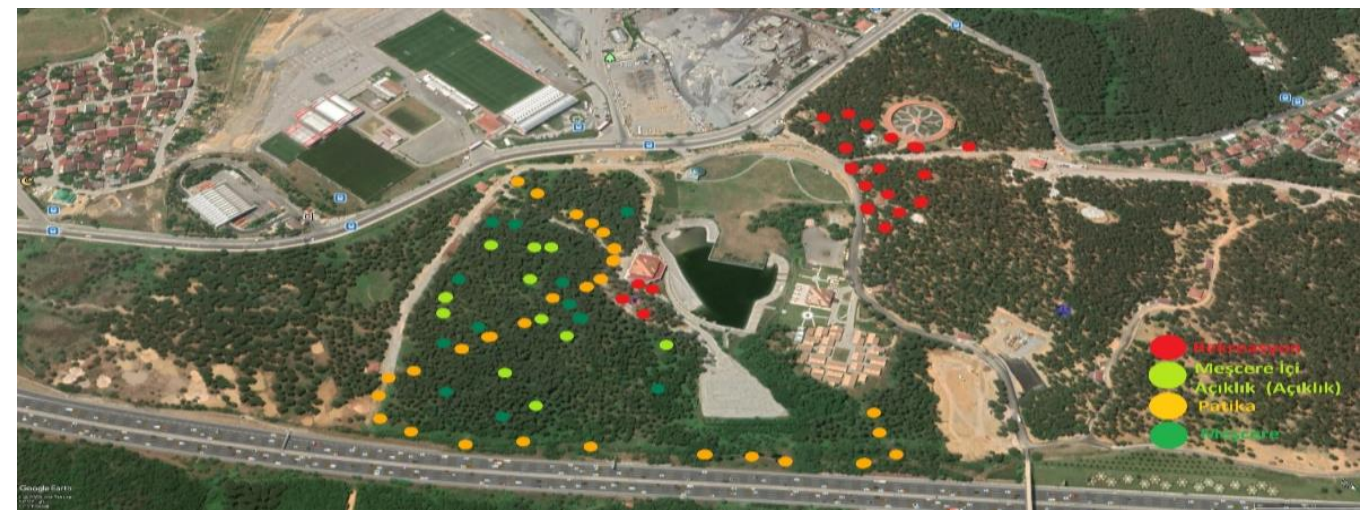

Şekil 1.Çalışma alanına ait uydu görüntüsü (Kırmızı noktalar: Rekreasyonel kullanımı olan alanlar, Açık yeşil olan alanlar: Meşcere içi açıklıkları, Sarı alanlar: Patikaları ve Koyu yeşil alanlar: Meşcere yapısı bozulmamış alanları tanımlamaktadır.)[19]

\section{A. 1. Örneklerin Toplanması ve Laboratuvar Analizleri}

Her bir kullanım alanını temsilen rastgele olarak belirlenen 10'ar noktadan toprak sıkışması ve ölü örtü yoğunluğunun değişiminin tespit edilmesi amacıyla örnekler toplanmıştır. Sahaya ait ölü örtü örneklemeleri belirlenen 15 nokta üzerinde, $30 \times 30 \mathrm{~cm}$ 'lik alanlarda toprak üzerindeki tüm ölü örtünün toplanmasıyla gerçekleştirilmiştir. Daha sonra bu noktalarda açıkta kalan mineral topraktan başlamak üzere $0-10 \mathrm{~cm}$ ve $10-20 \mathrm{~cm}$ derinliklerden ikişer set toprak örneği alınmıştır. Bunlardan birinci seti kürekler yardımıyla alınarak fiziksel ve kimyasal analizler için kullanılmış, diğer set de bozulmamış 
toprak örneği olarak toprak hacim ağırlığının belirlenmesi için kullanılmıştır. Bunun için yaklaşık $100 \mathrm{~cm}^{3}$ hacimlerde paslanmaz çelikten oluşan silindirlerden oluşan toprak hacim ağırlı̆̆ örnekleyicileri kullanılmıştır. Sahadan toplanan tüm örnekler analiz için Düzce Üniversite Orman Fakültesi Orman Mühendisliği Bölümü Toprak Laboratuvarına getirilmiştir.

Alınan toprak örnekleri etiketlerinin bulunduğu haznelerde öncelikli olarak yaklaşık iki hafta oda sıcaklığında kurutularak hava kurusu hale getirilmiş ve hava kurusu hale getirilen örnekler porselen havanlarda dövülerek keseklerinden ayrıştııılmıştır. Dövülen toprak örnekleri, iskelet miktarının belirlenmesi ve toprak analizlerinin yapılması için çapı $2 \mathrm{~mm}$ olan eleklerden elenmiştir. Hem elekten geçen toprak hem de elek üstünde kalan toprağın taşlı kısmı tartılarak kaydedilmiştir. Kaydedilen değerler üzerinden daha sonra her bir örneğe ait iskelet (taşl1lık) miktarları \% oranlarla hesaplanmıştır. Eleklerden geçirilerek hazırlanan toprak örneklerinde toprak reaksiyonu $(\mathrm{pH})$, elektrik iletkenliği (EC), toprak tanecik bileşimi (tekstür), toplam kireç miktarı, organik madde (OM) içeriği, organik ve inorganik karbon (OC ve IOC) içeriği, katyon değişim kapasitesi (KDK) ve azot $(\mathrm{N})$ içeriği analizleri yapılmıştır.

Laboratuvara getirilen toprak örneklerinden hacim ağırlığı için alınan bozulmamış toprak örnekleri kese kâğıtları içerisinde kurutma firınında $105{ }^{\circ} \mathrm{C}$ 'de 24 saat kurutulup hassas terazide tartıldıktan sonra toprağın hacim ağırlıkları hesaplanmıştır. Toprak örneklerinin tanecik bileşimi (tekstür) analizleri Bouyoucos Hidrometre Yöntemi'ne göre yapılmış olup [20-21], bulunan kum, kil ve toz oranlarına göre Amerikan Toprak Tekstür Üçgeni'nden [22] yararlanılarak toprağın türü belirlenmiştir. Toprağın pH'sını belirlemek için hava kurusu toprak örnekleri 1/2,5 oranında saf su karışımı ile $\mathrm{pH}$ metre kullanılarak çözelti asitliği olarak belirlenmiştir [23-25]. Toprağın elektrik iletkenliğini belirlemek için hava kurusu toprak örnekleri $1 / 5$ oranında saf su karıştırılarak cihaz yardımıyla okumalar yapılmıştır [26]. Toprağın katyon değişim kapasitesi (KDK) sodyum asetat yöntemiyle bulunmuştur [27-28].Toprağın Organik Madde (OM) içeriği ateşte kayıp yöntemine göre belirlenmiştir [29]. Toprağın OC içeriği OM'nin \%50'si olarak hesaplanmıştır [30]. Toplam kireç $\left(\mathrm{CaCO}_{3}\right)$ miktarı Scheibler kalsimetresi ile belirlenmiştir [31]. Toprağın inorganik karbon (IOC) miktarı toplam kireç içerisindeki $\mathrm{C}$ miktarının hesaplanmasıyla elde edilmiştir. IOC ve C miktarları toplanarak toplam C miktarları (TOPC) hesaplanmıştır. Azot analizi ise Kjeldahl yöntemi ile belirlenmiştir (Kjeltec Auto 1030 Analyzer)[32].

Değişkenler arasındaki ilişkilere örnekleme desenine uygun olarak varyans analizi (ANOVA) yapılarak bakılmıştır. İstatistiki olarak önemli farklılıklar bulunan değişkenler için ortalamaları ayırma işlemi olarak Tukey'in HSD testi $\alpha=0.05$ güven düzeyinde uygulanmıştır. Bütün istatistiki analizler için SAS [33] programından yararlanılmıştır. Sonuçların $\mathrm{P}<0,05$ güven düzeyinde istatistiki olarak önemli olduğu kabul edilmiştir.

\section{BULGULAR}

Örnekleme yapılan alanlarda mineral toprak yüzeyinde bulunan ölü örtü miktarları farklı kullanım yoğunluklarına göre Şekil 2'de karşılaştırılmıştır. Şekil 2'de görüldügü üzere az yoğun olarak kullanılan meşcere içerisindeki ölü örtü miktarının, yoğun olarak kullanılan rekreasyon alanları ve en yoğun olarak kullanılan patika yollarına kıyasla yaklaşık 2 kat daha fazla olduğu belirlenmiştir. Topraktaki sıkışma oranının belirlenmesi için yapılan hacim ağırlığı analizinde Şekil 2'de görüldüğü gibi yoğun kullanımın olduğu patika yolarında $0-10 \mathrm{~cm}$ ve $10-20 \mathrm{~cm}$ derinlik kademelerinde, toprak örneklerinin hacim ağırlı̆̆ının meşçere alanlarından istatistiki olarak farklı çıktığı belirlenmiştir. Yapılan hesaplamalara göre en yoğun kullanıma sahip patika yollarında, her iki toprak derinliği kademesindeki toprak hacim ağırlığı, az yoğun olarak kullanılan meşçere alanlarına kıyasla yaklaşık 1,5 kat fazla çıkmıştır. Dolayısıyla yoğun olarak kullanılan patika yollarındaki toprak sıkışmasının, nispeten daha az yoğun olarak kullanılan meşçere ve meşçere içi açıklık alanlara oranla istatistiki olarak arttığı belirlenmiştir. 
Şekil 3'teki verilerde farklı kullanım yoğunluğuna sahip alanlardaki toprağın iskelet (taşl1lık) miktarları gösterilmektedir. Buna göreyoğun kullanıma sahip patika yollarında üst toprağın iskelet miktarının, meşçere ve rekreasyon alanlarına oranla yaklaşık 1,7 kat daha fazla olduğu, alt toprakta ise yine patika olarak kullanılan alanın meşçere, meşçere içi açıklık ve rekreasyon alanlarına oranla yaklaşık 1,5-1,7 kat daha fazla iskelet miktarına sahip olduğu hesaplanmıştır. Az yoğun kullanım alanları olan meşçere ve meşçere içi açıklık alanlar ile yoğun kullanım alanı olarak kullanılan rekreasyon alanları arasında toprak sıkışması bakımından bir farklılık olduğuna dair yeterli kanıt bulunamamıştır.

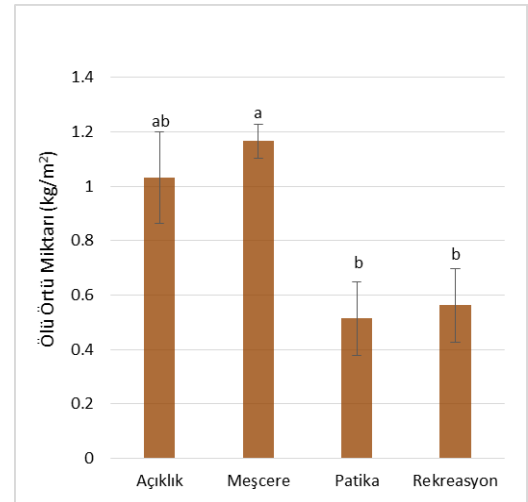

(a)

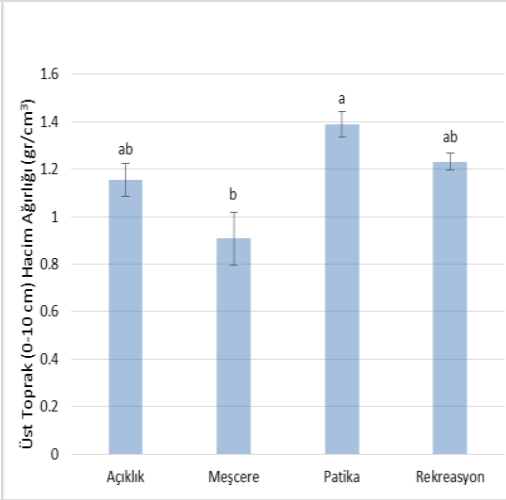

(b)

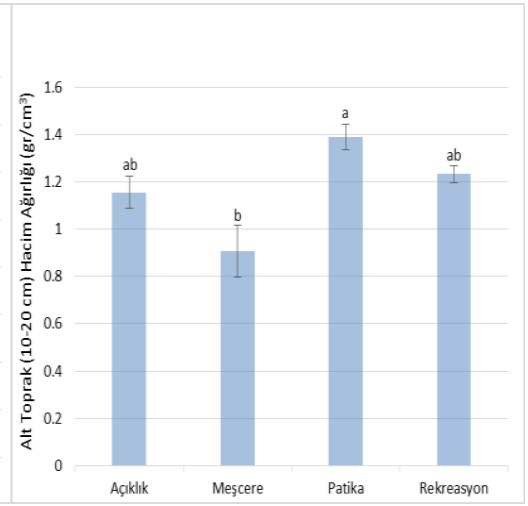

(c)

Şekil 2.Farklı yoğunlukta kullanılan alanlardakiortalama ölü örtü miktarl(a)ve üst toprak (b)ile alt toprak(c) hacim ağırlıkları. Not: Hata çubukları standart hatayı gösterirken çubuklar üzerindeki ortak harflerle takip edilen ortalamalar $\alpha=0,05$ düzeyinde istatistiki olarak birbirlerinden farklı değillerdir.

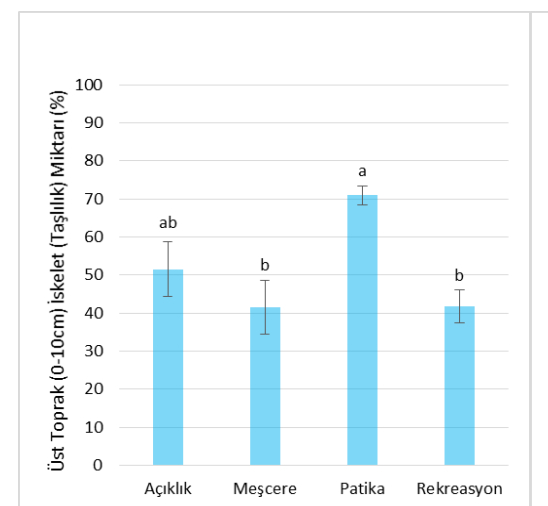

(a)

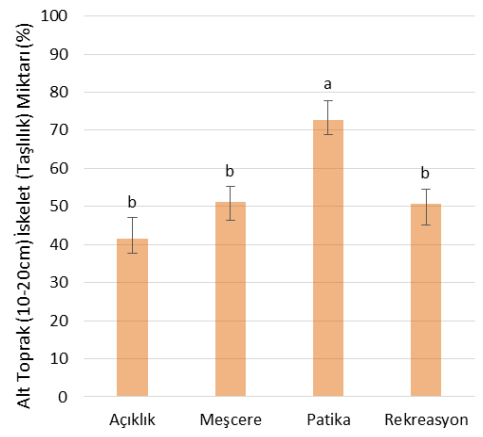

(b)

Şekil 3.Farkl yoğunlukta kullanılan alanlardaki üst toprak(a) ve alt toprak (b) iskelet miktarları.Not: Hata çubuklarl standart hatayı gösterirken çubuklar üzerindeki ortak harflerle takip edilen ortalamalar $\alpha=0,05$ düzeyinde istatistiki olarak birbirlerinden farklı değillerdir.

Çalışma alanına ait toprak tanecik bileşimi (tekstür)grafiği Şekil 4'de verilmiştir. Buna göre bütün alanların toprak türü ağırlıklı olarak kumlu balçık olarak bulunsa da, yer yer killi balçık, balçık ve kil tipinde toprak türleri de tespit edilmiştir. Üst topraktaki kum verileri incelendiğinde, yoğun olarak kullanılan rekreasyon alanındaki toprakların kum miktarları ile diğer alanların kum miktarları arasında yaklaşık 1,5 kat fark olduğu hesaplanmıştır. Alt toprakta ise yine en yüksek kum oranı rekreasyon alanında tespit edilmiş olup, bu oran orman içi açıklık alanların yaklaşık 2 katı, patika alanlarının 1,4 katı kadardır. Üst toprakta patika olarak kullanılan alandaki kil miktarının kum miktarının tersine, en düşük oranda bulunduğu yer rekreasyon alanları olup, diğer alanlarda ortalama 1,5-2 kat daha fazla kil tespit edilmiştir. Toz miktarları karşılaştırıldığında ise kullanım yoğunlukları arasında her iki derinlik kademesinde de anlamlı bir farklılık olduğuna dair kanıta rastlanılmamıştır. Genel olarak kullanım şekline bağlı topraktaki kum ve kil yoğunluklarının değişime uğradığı, yoğunluğun fazla olduğu yerlerde kil miktarının azaldığı, bunun yerine kum miktarının arttığı tespit edilmiştir. 
Çalışma sahasındaki toprakların reaksiyonu ve elektrik iletkenliği değerleri Şekil 5'de görülmektedir. Burada toprak reaksiyonunun $(\mathrm{pH})$ hem üst toprak hem de alt toprak bakımından alanlar aras1 farklılıklar gösterdiği belirlenmiştir. Buna göre insan faaliyetlerinin daha yoğun olduğu patikalarda ve rekreasyon alanlarında üst toprak daha alkalen bir özellik gösterirken, kullanım yoğunluğunun daha az olduğu meşçere ve meşçere içi açıklık alanlarda hafif asidik özellik göstermektedir. Bu durum alt toprakta değişerek toprak reaksiyonu en yoğun kullanılan patikalarda, az yoğun kullanılan meşçere ve meşçere içi açıklık alanlarda hafif asidik özellik gösterirken, rekreasyon alanlarında üst topraktakine benzer alkalen özellik göstermektedir. Toprakların tuzluluk miktarı ile ilgili bir gösterge olan elektrik iletkenliği (EC) incelendiğinde ne üst toprakta ne de alt toprakta bir tuzluluk sorunu tespit edilmemiştir. Ancak Şekil 5'de görüldügüü üzere alt topraktaki EC değerlerinin bariz bir şekilde rekreasyon alanlarında 3-6 kat arttı̆̆ belirlenmiştir.

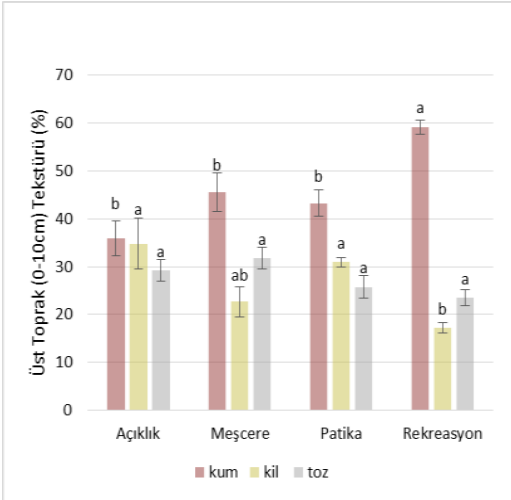

(a)

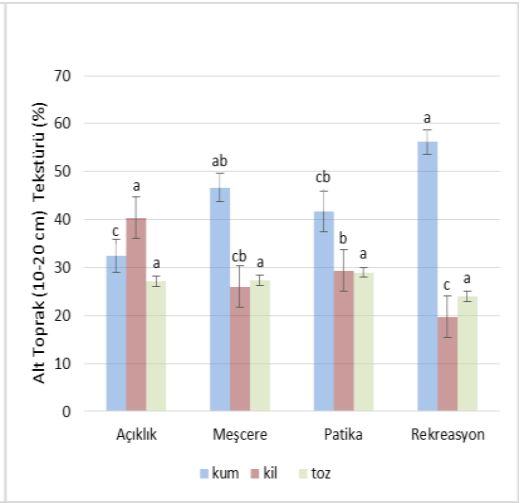

(b)

Şekil4.Farklı yoğunlukta kullanılan alanlardaki üst toprak (a) ve alt toprak (b) tekstürü.Not: Hata çubukları standart hatayı gösterirken aynı değişken için çubuklar üzerindeki ortak harflerle takip edilen ortalamalar $\alpha=0,05$ düzeyinde istatistiki olarak birbirlerinden farklı değillerdir.

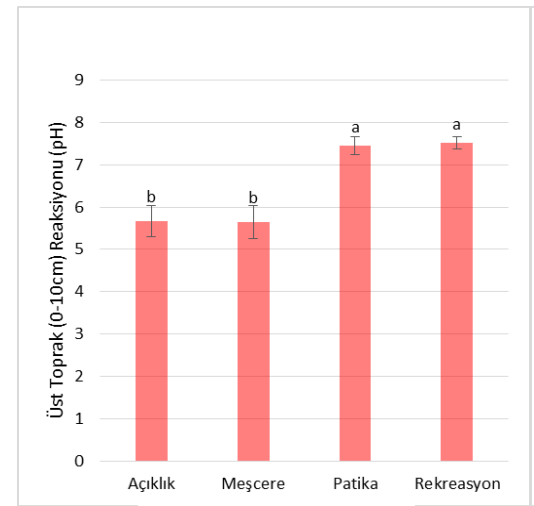

(a)

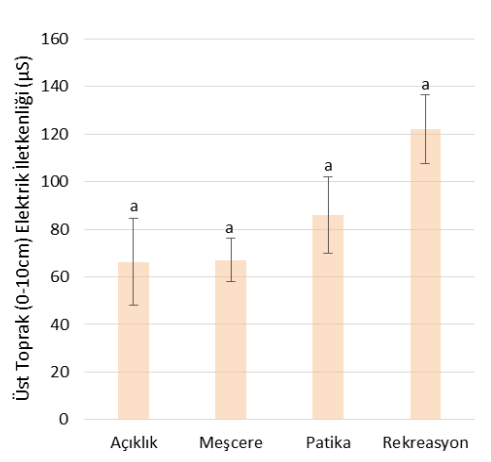

(b)

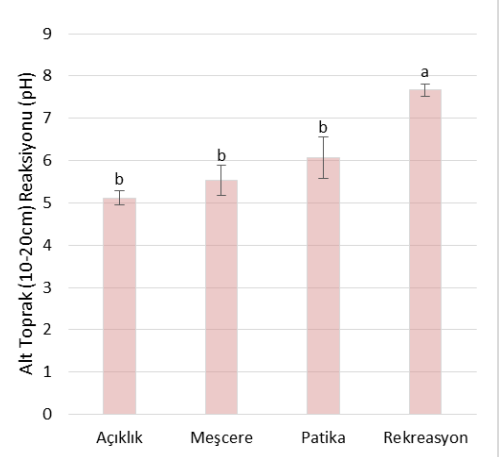

(c)

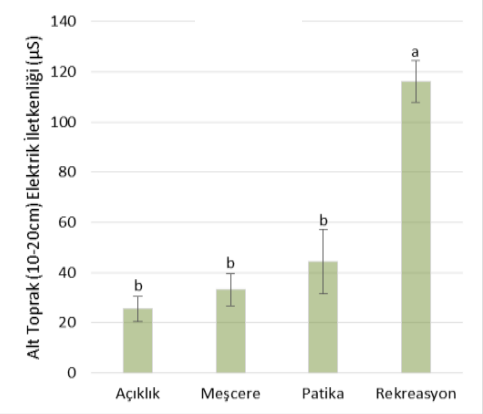

(d)

Şekil 5.Farklı yoğunlukta kullanılan alanlardaki üst toprak reaksiyonu (a)ve elektrik iletkenliği (EC) dĕgeri(b) ile alt toprak reaksiyonu (c)ve elektrik iletkenliği $(E C)$ değeri (d).Not: Hata çubuklart standart hatayı 
gösterirken çubuklar üzerindeki ortak harflerle takip edilen ortalamalar $\alpha=0,05$ düzeyinde istatistiki olarak birbirlerinden farklı değillerdir.

Kimyasal toprak özelliklerinden toprak verim gücünün bir göstergesi olan KDK değerleri Şekil 6'da görüldüğü gibi alanlar arasında farklılık göstermiş̧tir. Üst toprak ve alt toprak değerleri incelendiğinde az yoğun olarak kullanılan meşçere alanının KDK değeri anlamlı derecede diğer alanlara oranla farklı çıkmıştır. Buna göre her iki toprak derinlik kademesinde de az yoğun kullanılan meşcere içerisindeki KDK değeri benzer yoğunlukta kullanılan meşcere içi açıklık alandan yaklaşık 2 kat, yoğun kullanılan rekreasyon alanından ise yaklaşı 1,5 kat daha fazla olduğu tespit edilmiştir. IOC miktarının hesaplanabilmesi için yapılan kireç analizleri sonuçlarına göre toplam kireç oranları sahalar arası karşılaştırıldığında Şekil 7'de de görüldügü gibi istatistiki olarak bir fark bulunamamıştır.

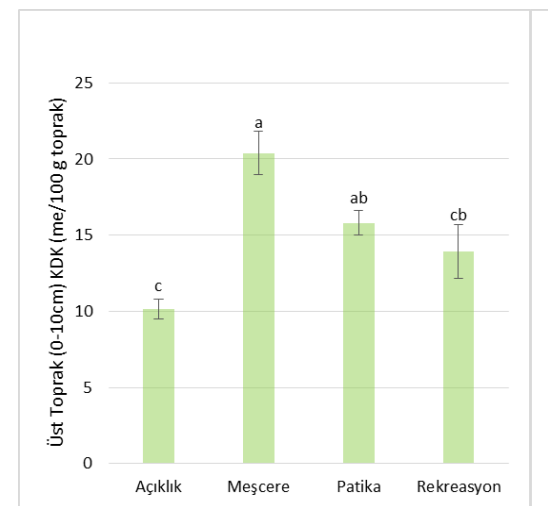

(a)

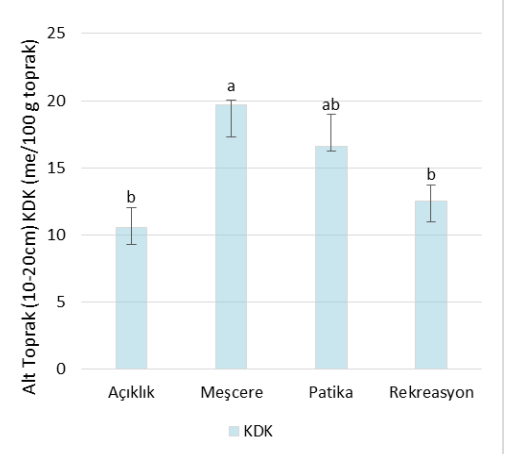

(b)

Şekil 6. Farkl yoğunlukta kullanılan alanlardaki üst toprak (a) ve alt toprak (b) katyon değişim kapasitesi (KDK).Not: Hata çubukları standart hatayı gösterirken aynı değişken için çubuklar üzerindeki ortak harflerle takip edilen ortalamalar $\alpha=0,05$ düzeyinde istatistiki olarak birbirlerinden farklı değillerdir.

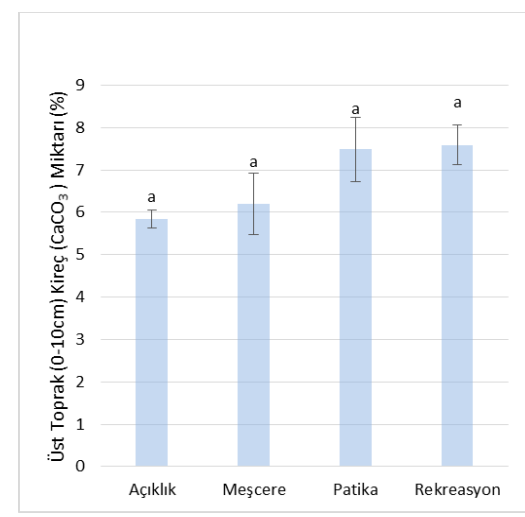

(a)

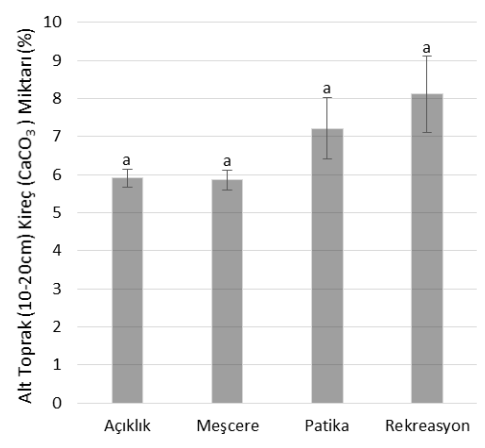

(b)

Şekil 7.Farklı yoğunlukta kullanılan alanlardaki üst toprak (a) ve alt toprak (b) toplam kireç $\left(\mathrm{CaCO}_{3}\right)$ miktarları. Not: Hata çubukları standart hatayı gösterirken aynı değişken için çubuklar üzerindeki ortak harflerle takip edilen ortalamalar $\alpha=0,05$ düzeyinde istatistiki olarak birbirlerinden farkl değillerdir.

Toprak içerisindeki OM oranları Şekil 8 ve Şekil 9'da görülmektedir. Az yoğun olarak kullanılan meşcere içerisindeki üst topraktaki $\mathrm{OM}$ oranının, en yoğun olarak kullanılan patika alanlarından yaklaşı 2,4 kat daha fazla olduğu hesaplanmıştır. OM miktarına paralel olarak OC oranları arasında da benzer bir eğilim tespit edilmiş, Şekil 8 ve Şekil 9'dada görüldüğü üzere meşçere alanlarında OC oranının patika alanlarına oranla 3,3 kat daha fazla olduğu tespit edilmiștir. Hem üst hem de alt topraktaki IOC oranları arasında farklı kullanım yoğunluğuna bağlı istatistiki olarak anlamlı bir fark bulunamamıştır. 


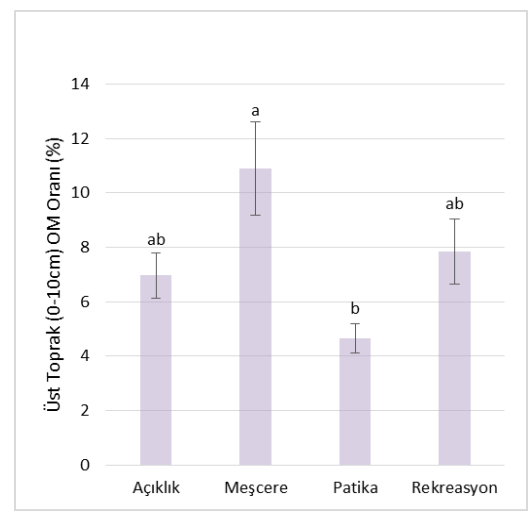

(a)

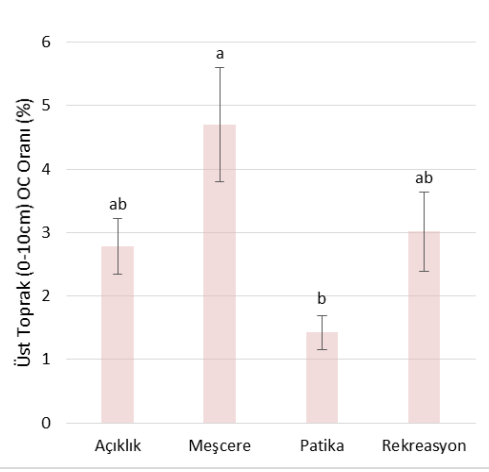

(b)

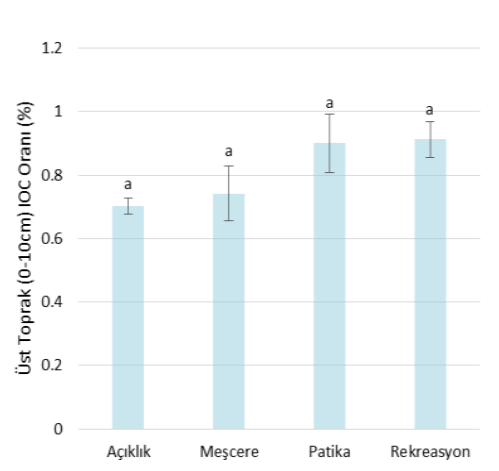

(c)

Şekil 8. Farklı yoğunlukta kullanılan alanlarda üst topraktaki (a) organik madde (OM),(b) organik karbon (OC) $v e(c)$ inorganik karbon (IOC) oranları.Not: Hata çubukları standart hatayı gösterirken aynı değiş̧ken için çubuklar üzerindeki ortak harflerle takip edilen ortalamalar $\alpha=0,05$ düzeyinde istatistiki olarak birbirlerinden farklı değillerdir.

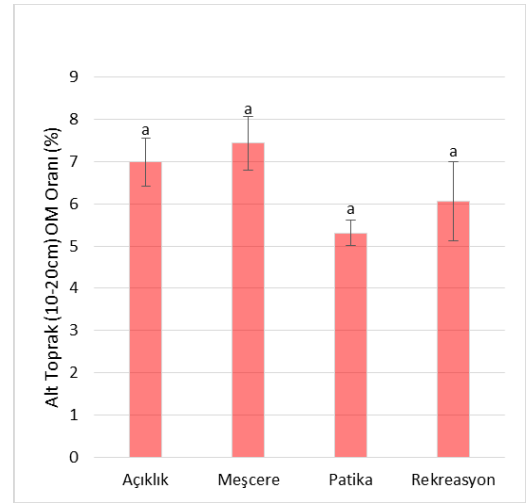

(a)

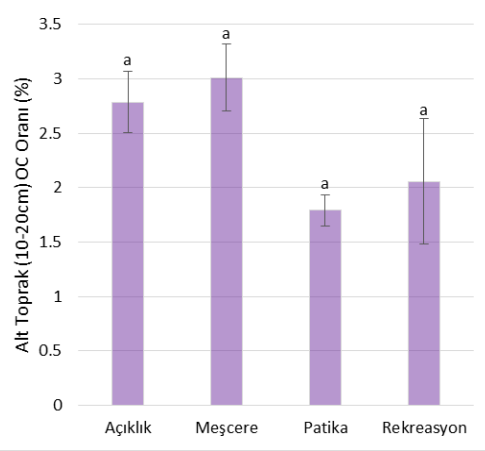

(b)

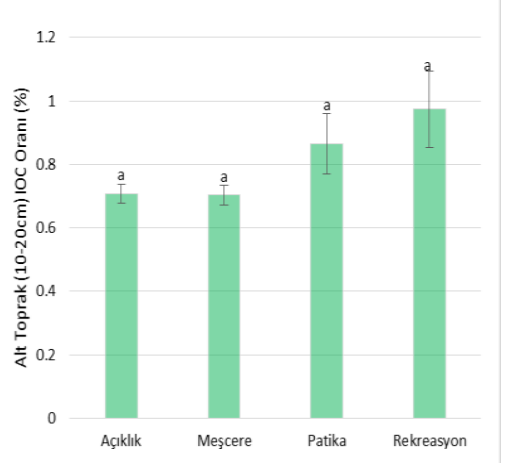

(c)

Şekil 9.Farklı yoğunlukta kullanılan alanlarda alt topraktaki(a) organik madde (OM),(b) organik karbon (OC) ve (c) inorganik karbon (IOC) oranları.Not: Hata çubukları standart hatayı gösterirken aynı değişken için çubuklar üzerindeki ortak harflerle takip edilen ortalamalar $\alpha=0,05$ düzeyinde istatistiki olarak birbirlerinden farklı değillerdir.

Şekil 10'da üst toprak ve Şekil 11'de alt toprak değerleri olmak üzere, toprak hacim ağırlıkları kullanılarak OC, IOC ve TOPC miktarları hektar bazında hesaplanmıştır. Burada sadece hektardaki IOC miktarları alanlar arasında farklılık göstermiştir. Hem üst toprakta hem de alt toprakta patika alanlarındaki IOC miktarı, meşçere alanlarının yaklaşık 2 katı olarak hesaplanmıştır. Şekil 10'daki üst toprak ve Şekil 11'deki alt toprağa ait OC ve TOPC miktarlarına bakıldığında, bu değerlerin alanlar arasında farklılık göstermediği belirlenmiştir.

Şekil 12'de görüldüğü üzere çalışma sahalarındaki her iki toprak derinlik kademesine ait $\mathrm{N}$ oranları, az yoğun olarak kullanılan meşçere ve yoğun olarak kullanılan rekreasyon alanlarında, çok yoğun olarak kullanılan patika alanlarından yaklaşık 2,5 kat fazla çıkmıştır. Ancak Şekil 12'de hacim ağırlığından faydalanılarak hesaplanan hektardaki N miktarlarına bakıldığında, bu miktarların alanlar arasında istatistiki olarak farklılık göstermediği tespit edilmiştir. 


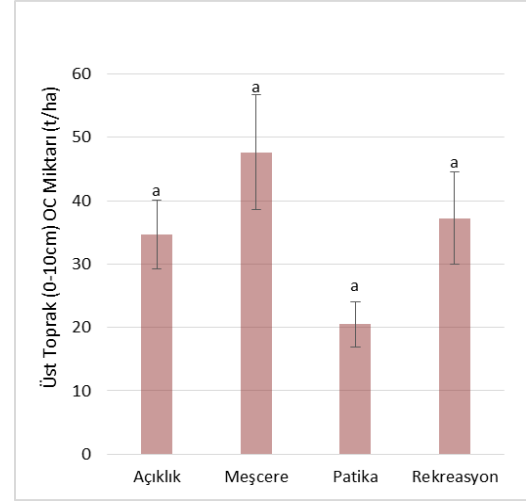

(a)

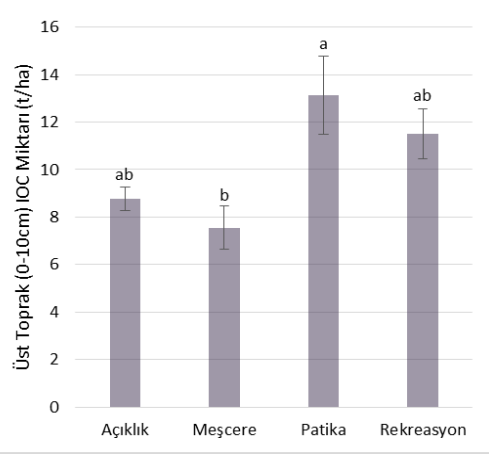

(b)

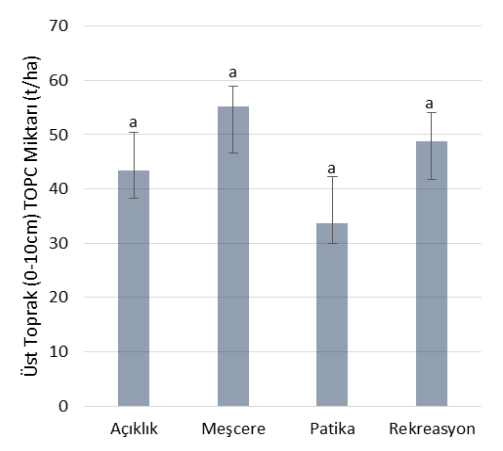

(c)

Şekil 10.Farkl yoğunlukta kullanılan alanlarda üst topraktaki (a) organik karbon (OC), (b) inorganik karbon (IOC) ve (c) toplam karbon (TOPC) miktarları (t/ha). Not: Hata çubukları standart hatayı gösterirken aynı değişken için çubuklar üzerindeki ortak harflerle takip edilen ortalamalar $\alpha=0,05$ düzeyinde istatistiki olarak birbirlerinden farklı değillerdir.

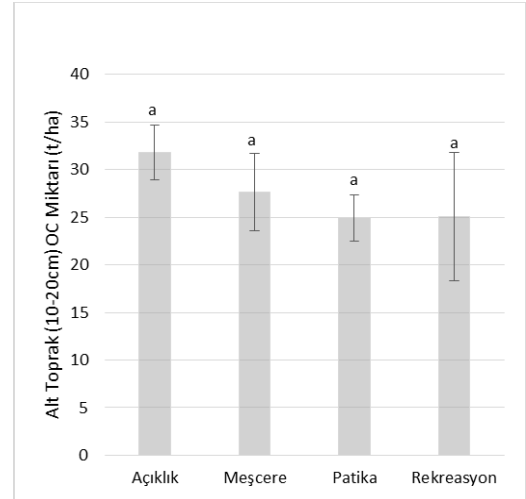

(a)

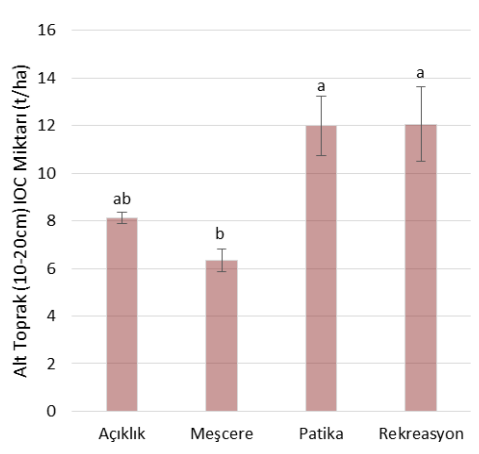

(b)

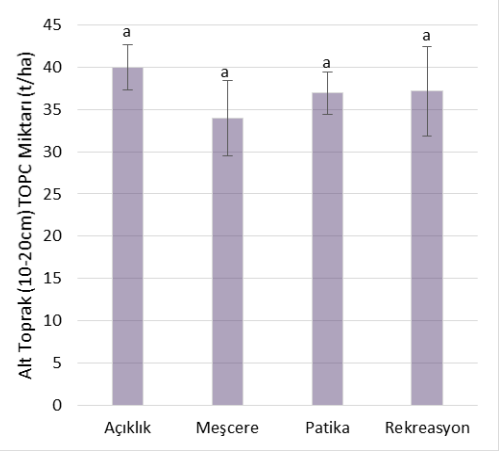

(c)

Şekil 11.Farkl yoğunlukta kullanılan alanlarda alt topraktaki (a) organik karbon (OC),(b) inorganik karbon (IOC) ve (c) toplam karbon (TOPC) miktarları (t/ha). Not: Hata çubukları standart hatayl gösterirken aynı değişken için çubuklar üzerindeki ortak harflerle takip edilen ortalamalar $\alpha=0,05$ düzeyinde istatistiki olarak birbirlerinden farklı değillerdir. 


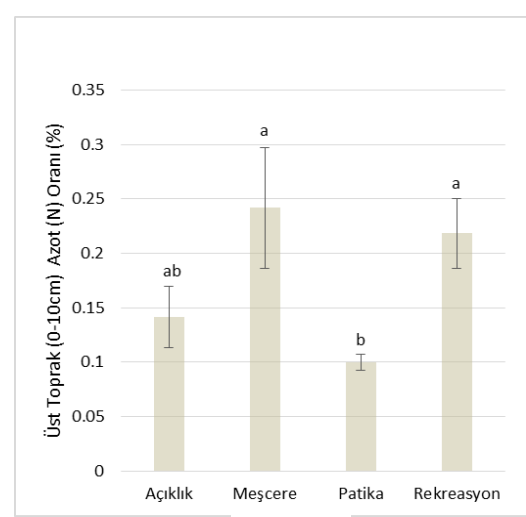

(a)

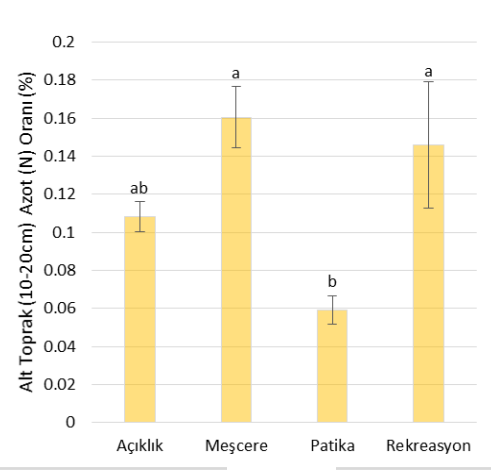

(b)

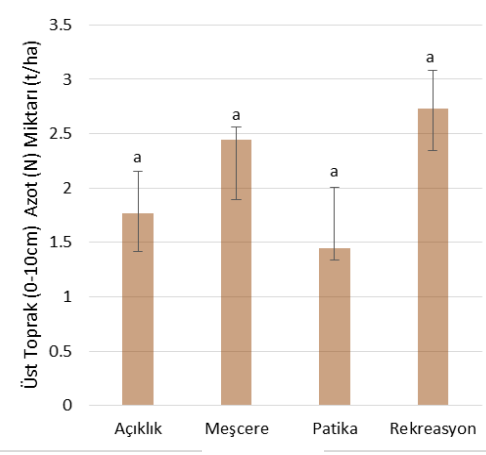

(c)

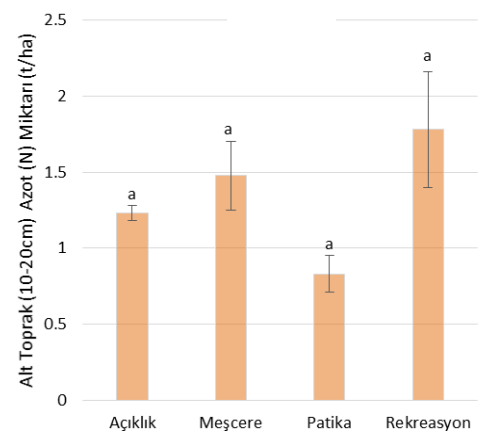

(d)

Şekil 12.Farkl yoğunlukta kullanılan alanlardaki üst toprak ve alt topraktaki azot (N) yoğunluklarl(a) üst toprak, (b) alt toprak) ile miktarları(c) üst toprak, (d)alt toprak) (t/ha).Not: Hata çubuklarl standart hatayl gösterirken aynı değişken için çubuklar üzerindeki ortak harflerle takip edilen ortalamalar $\alpha=0,05$ düzeyinde istatistiki olarak birbirlerinden farklı değillerdir.

\section{TARTISMA VE SONUC}

Doğada yapılan rekreasyonel faaliyetlere katılım bugün olduğu gibi, gelecekte de büyük kitleler halinde devam edecektir. Doğal alanların bu yoğun kullanımdan olumsuz etkilendiği bilinen bir gerçektir [14]. Rekreasyonel amaçlı olarak yürütülen faaliyetlerin çoğunun özellikle toprak üzerindeki etkileri büyük oranda benzerlik göstermektedir. Erozyona ve toprak sıkışmasına neden olma gibi zararları içeren bu etkiler, toprakta su hareketini etkilemekte bunun yanında köklerin ve ana kayanın yüzeye çıkmasına neden olmakta, bu durum da ekosistemde geriye dönüşü zor olan büyük tahribatların meydana gelmesine zemin hazırlamaktadır[13].Nitekim rekreasyonel kullanımların ekolojik etkilerini inceleyen çalışmalarda, rekreasyonun toprak ve bitki örtüsüne etkisinin şiddetli ve uzun süreli olduğu vurgulanmaktadır[34].

Rekreasyonel faaliyetlerde farklı kullanım tiplerinin karşılaştırılması amacıyla yapılan bu çalışmada kullanım yoğunluğunun ölü örtü miktarını istatistiki olarak değiştirdiği, az yoğun olarak kullanılan meşcere içerisindeki ölü örtü miktarının, yoğun olarak kullanılan rekreasyon alanları ve en yoğun olarak kullanılan patika yollarına kıyasla yaklaşık 2 kat daha fazla olduğu belirlenmiştir. İstanbul Belgrad Ormanı'nda yapılan benzer bir çalışmada da yoğun olarak kullanılan alanlardaki ölü örtü miktarının bozulmamış alanlara oranla aynı şekilde 2 kat fazla olduğu belirlenmiştir [12]. Yapılan birçok çalışmada rekreasyonel kullanım yoğunluğunun artmasına paralel olarak ölü örtü miktarının azaldığı tespit edilmiştir [34-39].

Yoğun kullanıma sahip patika yollarında, hem üst toprakta $(0-10 \mathrm{~cm})$ hem de alt toprakta $(10-20 \mathrm{~cm})$ toprak hacim ağırlı̆̆ı, az yoğun olarak kullanılan meşçere ve meşçere içi açıklık alanlarına kıyasla yaklaşık 1,5 kat fazla çıkmıştır. Dolayısıyla yoğun olarak kullanılan patika yollarındaki toprak 
sıkışmasının, nispeten daha az yoğun olarak kullanılan meşçere ve meşçere içi açıklık alanlara oranla arttığı tespit edilmiştir. Doğal alanlarda yapılan rekreasyonel faaliyetlerden yürüyüş [10,40-42] ve piknik [3,11,12] gibi yoğun insan katılımının olduğu faaliyetlerin neden olduğu baskıdan dolayı [4345] şimdiki çalışmadakine benzer şekilde toprak sıkışmasının arttı̆̆ı yapılan birçok çalışmada ortaya konmuştur. $\mathrm{Bu}$ yoğun kullanım sonucu ortaya çıkan toprak sıkışmasının yanı sıra bir diğer etki de toprak kaybıdır [39,46-47]. Nitekim yoğun kullanıma sahip patika yollarında üst toprağın iskelet miktarının, meşçere ve rekreasyon alanlarına oranla yaklaşık 1,7 kat daha fazla olduğu, alt toprakta ise yine patika olarak kullanılan alanın meşçere, meşçere içi açılık ve rekreasyon alanlarına oranla yaklaşık 1,5-1,7 kat daha fazla iskelet miktarına sahip olduğu hesaplanmıştır. Bu durumda özellikle yoğun kullanımın toprak kaybına yol açtığ kuvvetle muhtemeldir.

Genel olarak kullanım şekline bağlı topraktaki kum ve kil yoğunluklarının değişime uğradığı, kullanım yoğunluğunun fazla olduğu yerlerde kil miktarının azaldığı, bunun yerine kum miktarının arttığı tespit edilmiştir. Ancak toprak tanecik bileşiminin direkt kullanım yoğunluğuna bağlı olduğunu gösteren yeterli kanıta ulaşılamamıştır. Toprak tekstüründeki benzer değişimler rekreasyonel faaliyetlerin toprak üzerine yaptığı etkiler ile ilgili yapılan çalışmaların çoğunda görülse de,bu çalışmaların genel sonucu rekreasyonel faaliyetlerin toprak tanecik bileşimine etki etmediği yönündedir [12,40-41].

İnsan faaliyetlerinin daha yoğun olduğu patikalarda ve rekreasyon alanlarında üst toprak daha alkalen bir özellik gösterirken, kullanım yoğunluğunun azaldığı meşçere ve meşçere içi açıklık alanlarda hafif asidik özellik göstermektedir. Bu durum alt toprakta değişerek toprak reaksiyonu en yoğun kullanılan patikalarda, az yoğun kullanılan meşçere ve meşçere içi açıklık alanlarda hafif asidik özellik gösterirken, rekreasyon alanlarında üst topraktakine benzer alkalen özellik göstermektedir. Her ne kadar yapılan bazı çalışmalarda kullanım yoğunluğunun toprak reaksiyonunu etkilemediği belirtilse de [37,40,48], çoğu çalışmada kullanım yoğunluğu arttıkça toprak reaksiyonunun alkalenleştiği belirtilmektedir [12, 36, 37, 43, 44]. Bu durum yoğun kullanım alanlarında ölü örtünün azalması ve buna bağlı ayrışan organik asitlerin toprağa sızmasının azalmasından kaynaklanıyor olabilir [34-39].

Genellikle kurumuş yaprak, dal ve odun parçalarından oluşan ölü örtü yoğun olarak kullanılan rekreasyon alanlarında azalma eğilimindedir. Özellikle piknik alanlarında sıklıkla ateş yakmak ya da tutuşturmak için kullanılmaktadır. Bu da toprağa doğal gübre işlevi gören ölü örtünün azalmasına neden olmakta, nihayetinde toprak verimliliği azalmaktadır [47, 49]. Bu da hem üst toprak hem de alt toprakta az yoğun olarak kullanılan meşçere alanının KDK değerinin, diğer alanlara oranla daha yüksek çıkması durumunu açıklamaktadır. Ölü örtü miktarının ve buna bağlı topraktaki OM oranının patika ve rekreasyon alanlarında azalması, bu alanlardaki toprağın alkalenleşmesi ve KDK değerinin düşmesi sürecinin nasıl birbirine bağlı olduğunu göstermesi bakımından oldukça önemlidir.

Az yoğun olarak kullanılan meşcere içerisindeki üst topraktaki OM oranının, en yoğun olarak kullanılan patika alanlarından yaklaşık 2,4 kat daha fazla olduğu, OM miktarına paralel olarak meşçere alanlarında OC oranının patika alanlarına oranla 3,3 kat daha fazla olduğu tespit edilmiştir. Dolayısıyla alanlar arasında kullanım yoğunluğu azaldıkça toprak içerisindeki OM ve OC oranlarının artmış olduğu belirlenmiştir. İsrail'de yapılan [50]ve ayrıca tropik alanlar ile subtropik alanları kapsayan bir alanda yapılan[51] çalışmalarda her ne kadar toprak OM içeriğinin kullanım yoğunluğuna bağlı olarak değişmediği iddia edilse de, çoğu çalışmada kullanım yoğunluğu arttıkça, toprak OM içeriğinin azaldığı belirtilmektedir [12,34-37,48,52]. Yine aynı şekilde kullanım yoğunluğunun artmasına paralel olarak toprak OC içeriğinin azaldığ yapılan birçok çalışmada tespit edilmiştir [12,35,40,48]. İstanbul Belgrad ormanlarında yapılan çalışmada bozulmamış orman alanlarındaki OC oranının piknik faaliyeti gerçekleştirilen alanlardan yaklaşık 6 kat daha fazla olduğu belirtilmiştir [12]. Türkiye ormanlarında toprak ve ölü örtüde depolanmış OC miktarları üzerine yapılan bir çalışmada $1 \mathrm{~m}$ derinlik için 1 ha alandaki topraktaki OC miktarı araştırılmış ve ibreli ağaçların hakim olduğu orman ekosistemlerinde $77,1 \mathrm{t} / \mathrm{ha}^{-1}$, yapraklı ağaçların hakim olduğu orman ekosistemlerinde ise 80,4 t/ha ${ }^{-1}$ olduğu bildirilmiştir [53]. Bu çalışmada derinlik olarak 1 metre kullanılmadığı için değerler farklılık gösterse de, organik karbonun en fazla olduğu üst topraktaki değerler toplam OC miktarının meşcere alanlarında benzer miktarlara ulaşıldığının göstergesidir. 
Ancak topraktaki değişkenliğin çok fazla olmasından dolayı OC ve TOPC miktarlarının kullanım yoğunluğuna bağlı bir farklılık gösterdiğine dair yeterli kanıta ulaşılamamıştır.

Toprak sıkışması sonucu makro gözeneklilikteki azalmayla beraber oksijen noksanlığı ortaya çıkmaktadır. Toprak havasının bileşiminde oksijen oranının azalması sonucu organik materyalin ve mikrobiyal biyokütlenin mikroorganizmalar tarafindan ayrıştırılması engellenmektedir. Bu nedenle sıkışmış topraklarda $\mathrm{N}$ mineralizasyonunda bir azalma meydana gelmekte ve azotun gaz halinde kaybı söz konusu olmaktadır [54-56]. İstanbul'da tahrip olmuş maden sahalarında yapılan bir çalışmada topraktaki OC miktarının artışı ile de toprak hacim ağırlığının azaldığı ve N oranının yükseldiği tespit edilmiştir [57]. Şimdiki çalışmada da bu durum benzerlik göstermiş alanlar arasında kullanım yoğunluğu azaldıkça toprak üstündeki ölü örtü miktarı, toprak içerisindeki OM ve OC oranları artmış, hacim ağırlığı azalmış ve $\mathrm{N}$ oranında da artış olduğu belirlenmiştir. Aynı zamanda topraktaki KDK değerlerinin de kullanım yoğunluğu azaldıkça arttığı, dolayısıyla toprak verim gücünün az yoğun kullanılan sahalarda daha iyi korunduğu tespit edilmiştir.

Rekreasyon alanlarında tahrip olmuş alanların restorasyonu önem arz eden diğer bir konudur. Bu gibi tahrip unsuru yüksek olan sahalarda özellikle kullanılacak bitki türlerinin ekolojik açıdan önemle ele alınması gereken konuların başında yer almaktadır[9]. Bu bağlamda şimdiki çalışma sahasındakine benzer rekreasyonel alanlarda mümkün olduğunca doğal ekosistem yapısını bozmadan rekreasyonel faaliyetlerin yapılmasını sağlamak özellikle toprak üzerindeki olumsuz etkilerin azaltılmasına yardımcı olabilir. Sahaya yapılacak bitkilendirme çalışmalarında o bölgeye has bitki türlerinin tercih edilmesi olumsuz koşulların düzeltilmesinde yardımcı olabilir. Sahada örneklemeler yapılırken daha yoğun insan aktivitesi görülen alanlarda bitki varlığının azaldığı, birkaç yer örtücü tür haricinde rekreasyon ve patika alanlarında toprağın çıplaklaştığı gözlemlenmiştir. Yoğun insan baskısının sürmesi sahada nispeten daha az yoğun olarak kullanılan meşçere ve meşçere içi açıklık alanlarında da benzer sonuçların ortaya çıkmasına neden olabilir. Bununla beraber son yıllarda etkisini iyice arttıran küresel ısınma ve beraberinde gelen kuraklık, sahalardaki hali hazırda oluşan stres koşullarının iyice artmasına ve Kuzey Avrupa'da görülen toplu bitki ölümleri gibi tahrip şiddeti yüksek sonuçların ortaya çıkmasına neden olabilir [58]. Nitekim N gibi bitki beslenmesi için önemli, ayrıca ekosistemde değişken ve bağlanması oldukça zor olan bir besin elementinin bu durumdan etkilenmesi bu tip ekosistemlerin sürdürülebilirliğini sekteye uğratabilir.

Sonuç olarak bu ve benzeri çalışmalar, rekreasyon alanlarındaki aktivitelerinin planlı ve kontrollü olarak sürdürülmesi gerektiğini, aksi halde ileriki dönemlerde kendi kendini yenileme eşiğini geçen ve geri dönüştürülmesi zor olan tahriplerin kuvvetle muhtemel ortaya çıkabileceğini göstermektedir. Hızla artan dünya nüfusu bir taraftan doğada yapılan rekreasyonel faaliyetlere katılımı arttırırken diğer taraftan doğal ekosistemleri olumsuz yönde etkilemektedir [14].Bu etkilerin en aza indirilmesi için alanın taşıma kapasitesinin toprak özelliklerine en az düzeyde zarar verecek şekilde planlanması gerekmektedir [11]. İnsanların tam alan yerine sahadaki belirli noktaları kullanması, yürüyüş yolları dışındaki alanlara insan girişlerinin azaltılması en başta alınacak önlemler olarak düşünülmektedir. $\mathrm{Bu}$ bağlamda insan faaliyetlerine açık alanların işletme yetkilisi olan kurum, kişi ya da kuruluşların farklı disiplinlerden oluşan bilimsel ve teknik bir heyet oluşturup, kullanım planlamasını bu heyetin görüş ve fikirlerine göre yapması büyük önem taşımaktadır. Oluşturulan koruma ve kaynak kullanma politikalarının, rekreasyonel kullanım ile ilgili yapılan bilimsel çalışmaların sonuçlarına göre tekrar gözden geçirilmesi ve planlamaların bu doğrultuda yapılması gerektiği düşünülmektedir.

TEŞEKKÜR: Bu çalışma TÜBITTAK 2209-A Üniversite Öğrencileri Araştırma Projeleri Destekleme Programı tarafından desteklenmiştir (Proje başvuru no: 1919B011900176). 


\section{KAYNAKLAR}

[1] E. P. Odum ve G.W. Barret, Ekolojinin Temel İlkeleri, Kani IŞIK, Ed., 5. baskı,Ankara, Türkiye: Palme Yayınc1lık, 2008.

[2] O. Yıldız, M. Sarginci, D. Eşen ve K. Jr. Cromack, "Effects of vegetation control on nutrient removal and Fagus orientalis, Lipsky regeneration in the Western Black Sea region of Turkey," For. Ecol. Manage. c. 240 ss. 186-194, 2007.

[3] S. Uzun, "Uludağ Milli Parki’ndaki rekreasyonel kullanimlarin ekosistemin bazi bileşenleri üzerine etkileri,” Doktora tezi, Peyzaj Mimarlığı, Fen Bilimleri Enstitüsü, Düzce Üniversitesi, Düzce, Türkiye, 2012.

[4] L. Van-Camp, B. Bujarrabal, A. R. Gentile, R. J. A. Jones, L. Montanarella, C. Olazabal ve S. K. Selavaradjou, "Reports Of The Technical Working Groups Established Under The Thematic Strategy For Soil Protection," Office for Official Publication of the European Communities, Luxemburg, EUR 21319 EN/6, 2004.

[5] B. Turgut, "Ormanlık alanlarda toprak sıkışması sorunu," SDÜ Orman Fakültesi Dergisi, c. 1, s. 13 , ss. $66-73,2012$.

[6] B. D. Soane ve C. Van Ouwerkerk, "Soil Compaction In Crop Production," Amsterdam, The Netherlands: Elsevier, 2013.

[7] W. R. Whalley, E. Dumitru ve A. R. Dexter, "Biological effects of soil compaction," Soil and Tillage Research, c. 35 s. 1-2, ss. 53-68, 1995.

[8] A. Gomez, R. F. Powers, M. J. Singer ve W. R. Horwath, "Soil compaction effects on growth of young ponderosa pine following litter removal in California's Sierra Nevada," Soil Science Society of America Journal, c. 66, s. 4, ss. 1334-1343, 2002.

[9] O. Yildiz, E. Altundağ, B. Çetin, Ş. T. Güner, M. Sarginci ve B. Toprak, "Afforestation restoration of saline-sodic soil in the Central Anatolian Region of Turkey using gypsum and sulfur," Silva Fennica, c. 51 s. 1B, ss.1-17, 2017.

[10] M. J. Liddle, Recreation Ecology: The Ecological Impact Of Outdoor Recreation And Ecotourism, Springer, 1997, ss. 639.

[11] A. Gül ve M. Akten, "Korunan doğal alanlarda rekreasyonel taşıma kapasitesi ve kavramsal yaklaşımlar”, Korunan Doğal Alanlar Sempozyumu, Isparta, Türkiye, 2005, ss. 485-494.

[12] M. Çakır, E. Makineci ve M. Kumbasl1, "Comparative study on soil properties in a picnic and undisturbed area of Belgrad forest, İstanbul," Journal of Environmental Biology, c. 31 ss. 125-128, 2010.

[13] C. M. Pickering, W. Hill, D. Newsomeb ve Y.F. Leung, "Comparing Hiking, Mountain Biking And Horse Riding impacts on vegetation and soils in Australia and The United States Of America," Journal of Environmental Management, c. 91, s. 3, ss. 551-562, 2010.

[14] F. Koçak ve V. Balcı, "Doğada yapılan sportif etkinliklerde çevresel sürdürülebilirlik," Ankara Üniversitesi Çevrebilimleri Dergisi, c. 2, s. 2, ss. 213-222, 2010. 
[15] M. Ö. Karaöz, "Belgrad Ormanı'nda bazı iğne yapraklı ve geniş yapraklı orman ekosistemlerine ait toprak özelliklerinin bir metreküp hacimdeki değerlere göre karşılaştırılması," İstanbul Üniversitesi Orman Fakültesi Dergisi, c. 41, s. 1, ss. 61-66, 1991.

[16] R. F. Kuss ve A. R. Grafe, "Effects of recreation trampling on natural area vegetation." $J$. Leisure Res.,c. 17 ss. 165-183, 1985.

[17] G. W. Kearsley, "Tourism development and users' perception of wilderness in Southern New Zealand.” Aust. Geogr. c. 21, ss. 127-140, 1990.

[18] Ümraniye Belediyesi Kent Ormanı ve İzci Kamp1. (2019, 25 Mart). [Online]. Erişim:https://projeler.umraniye.bel.tr/tr/projeler/proje/kent-ormani-ve-izci-kampi/54/kent-ormani-veizci-kampi/329

[19] İstanbul Hekimbaş1 Kent OrmanıGoogle Maps Uydu Görüntüsü.(2020, 1 Eylül). [Online]. Erişim:https://www.google.com/maps/place/Hekimba\%C5\%9F\%C4\%B1,+\%C4\%B0stanbul+Kent+O rman\%C4\%B1,+\%C3\%9Cmraniye\%2F\%C4\%B0stanbul/@41.0624259,29.1090061,783m/data=!3m1 !1e3!4m5!3m4!1s0x14cac9643988d2a3:0x836c5c71009bb5c5!8m2!3d41.0632389!4d29.1090276

[20] P. R. Day, "Particle fractionation and particle size-analysis," in Methods of Soil Analysis: Part 1, Madison, Wisconsin, USA: American Society of Agronomy, 1965, ss. 545-567.

[21] D. L. Sparks, A. L. Page, P. A. Helmke, R. H. Loepert, P. N. Soltanpour, M. A. Tabatabai, C. T. Johnston ve M. E. Sumner, "Chemical methods," in Methods of Soil Analysis: Part 3. Madison, Wisconsin, USA: Soil Science Society of America and American Society of Agronomy, 1996, ss. 9611010.

[22] USDA, "Soil mechanics level I. Module 3-USDA textural soil classification study guide," National Employee Development Staff, Soil Conservation Service, United States Department of Agriculture, Washington, DC, 1987.

[23] R. K. Schofield ve A. W. Taylor, "The measurement of soil pH," Soil Science Society of America Journal, c. 19, s. 2, ss.164-167, 1955.

[24] M. K. Conyers ve B. G. Davey, "Observations on some routine methods for soil pH determination," Soil Science, c. 145, s. 1, ss. 29-36, 1988.

[25] G.W. Thomas, "Soil pH and soil acidity," in Methods of Soil Analysis: Part 3. Madison, Wisconsin, USA: Soil Science Society of America and American Society of Agronomy, 1996, ss. 475-490.

[26] J. D. Rhoades, "Salinity: Electrical Conductivity And Total Dissolved Solids," in Methods of Soil Analysis: Part 3. Madison, Wisconsin, USA: Soil Science Society of America and American Society of Agronomy, 1996, ss. 417-436.

[27] M. G. Berg ve E. H. Gardner, "Methods Of Soil Analysis Used In The Soil Testing Laboratory At Oregon State University," Agricultural Experiment Station, Oregon State University, Corvallis, USA, Special Report 321, 1978.

[28] M. E. Sumner ve W. P. Miller, 1996. "Cation exchange capacity and exchange coefficients," in Methods of Soil Analysis: Part 3. Madison, Wisconsin, USA: Soil Science Society of America and American Society of Agronomy, 1996, ss. 1201-1229.

[29] R. Margesin ve F. Schinner, "Manual Of Soil Analysis. Monitoring And Assessing Soil Bioremediation,” Heidelberg, Germany: Springer Science \& Business Media, 2005. 
[30] A. Güneş, M. Alpaslan ve A. Inal, "Bitki Besleme ve Gübreleme," Ankara, Türkiye:Ankara Üniversitesi Ziraat Fakültesi Toprak Bölümü Ders Kitabı, Yayın No: 1539, 2004.

[31] F. Gülçur, "Toprağın Fiziksel ve Kimyasal Analiz Metodları," İstanbul, Türkiye: İstanbul Üniversitesi Orman Fakültesi Yayınları İ. Ü. Yayın No: 1970, O. F. Yayın No: 201 Kutulmuş Matbaas1, 1974, ss. 205.

[32] J. M. Bremner, "Nitrogen-Total," in Methods of Soil Analysis: Part 3. Madison, Wisconsin, USA: Soil Science Society of America and American Society of Agronomy, 1996, ss. 1085-1121.

[33] SAS Institute, Inc., SAS/STAT Users Guide, Version 6.12. SAS Institute, Inc., Cary, North Carolina, 1996.

[34] D. N. Cole, "Research on soil and vegetation in wilderness: A state-ofknowledge review." In: Proceeding. National Wilderness Research Conference: Issue, State-of-knowledge, Future Directions; 1985 July 23\}26; Fort Collins, CO. Gen Tech Rep INT-220. Ogden, UT: USDA Forest Service, Intermountain Research Station. ss. 135-177, 1987.

[35] P. Kutiel, H. Zhevelev ve R. Harrison, "The effect of recreational impacts on soil and vegetation of stabilised Coastal Dunes in the Sharon Park, Israel," Ocean Coast. Manage., c. 42, ss. 1041-1060, 1999.

[36] M. Andres-Abellan, J. B. Del Alamo, T. Landete-Castillejos, F. R. LopezSerrano, F. A. Garcia-Morote ve A. Del Cerro-Barja, "Impact of visitors on soil and vegetation of the recreational area "Nachimiento Del Rio Mundo" (Castilla-La Mancha, Spain)." Environ. Monit. Assess., c. 101, ss. $55-67,2005$.

[37] P. Kutiel, H. Zhevelev ve H. Lavee, "Coastal dune ecosystems: Management for conservation objective. III. Soil response to three vegetation types to recreational use." J. Mediterr. Ecol., c. 1, ss. 171-179, 2000.

[38] A. Duyar ve S. Kiniş, "The effects of trekking activities on physical soil properties in the Bolu-Aladağ fir forests," Forestist, c. 68, s. 1, ss. 36-41, 2018

[39] B. Ş. Güngör, "Cultural ecosystem services and recreational use: a review study in Belgrad Forest, Istanbul," Journal of Multidisciplinary Research in Sustainability. c. 1, s. 1, ss. 30-55, 2018.

[40] S. Y. Korkanç, "Impacts of recreational human trampling on selected soil and vegetation properties of Aladag Natural Park, Turkey," Catena, c. 113, ss.219-225, 2014.

[41] S. A. Lei, "Soil compaction from human trampling, biking, and off-roadmotor vehicle activity in a blackbrush (Coleogyne ramosissima) shrubland," Western North American Naturalist, c. 64, s.1, ss. $125-130,2004$.

[42] T. T. Kozlowski, "Soil compaction and growth of woody plants," Scandinavian Journal of Forest Research, c. 14, ss. 596-619, 1999.

[43] P. Sarah ve H. M. Zhevelev, "Effect of visitors' pressure on soil and vegetation in several different micro-environments in urban parks in Tel Aviv." Landscape Urban Plan., c. 83, ss. 284-293, 2007.

[44] J. M. Arocena, K. N. Sanjay, M. Rutherford, "Visitor-induced changes in the chemical composition of soils in backcountry areas of Mt Robson Provincial Park, British Columbia, Canada." J. Environ. Manage., c. 79, ss. 10-19, 2006. 
[45] M. J. Liddle ve P. J. Greigh-Smith, "A Survey of tracks and paths in a sand dune ecosystem. II. Vegetation,” J. Appl. Ecol., c. 12 ss. 899-908, 1975.

[46] J. L., Marion ve D. N. Cole, "Spatial and temporal variation in soil and vegetation impacts on campsites," Ecological Applications, c.6,ss.520-530, 1996.

[47] D. Pimentel ve N. Kounang, "Ecology of soil erosion in ecosystems." Ecosystems, c.1, ss.416426,1998 .

[48] M. Kissling, K. T. Hegetschweiler, H. P. Rusterholz ve B. Baur, "Short-term and longterm effects of human trampling on above-ground vegetation, soil density, soil organic matter and soil microbial processes in suburban beech forests," Applied Soil Ecology, c. 42, ss. 303-314, 2009.

[49] C. Demir, "Turizm ve rekreasyon faaliyetlerinin olumsuz çevresel etkileri: Türkiye' deki milli parklara yönelik bir uygulama," Dokuz Eylül Üniversitesi İ.I.B.F. Dergisi, c. 17, s. 2,ss. 93-117, 2002.

[50] P. Kutiel ve H. Zhevelev, "Recreational use impact on soil and vegetation at picnic sites in Aleppo pine forest on Mount Carmel, Israel," Isr. J. Plant Sci., c. 49, ss. 49-56, 2001.

[51] D. Sun ve M. J. Liddle, "A survey of trampling effects on vegetation and soil in eight tropical and subtropical sites," Environ. Manage., c. 17, ss. 497-510, 1993.

[52] H. Müderrisoğlu, M. Sargınc1, B. Toprak ve S. Uzun, "Effects of recreational usage-type and density on forest floor organic matter in Abant Nature Park," 1st International Turkey \& Japan Environment and Forestry Symposium, Trabzon, Turkey, 2010, ss.1562-1574.

[53] D. Tolunay ve A.Çömez, "Türkiye ormanlarında toprak ve ölü örtüde depolanmış organik karbon miktarları," Hava Kirliliği ve Kontrolü Ulusal Sempozyumu, Hatay, Türkiye, 2008, ss.750-765.

[54] J. M. Arocena, "cations in solution from forest soils subjected to forest floor removal and compaction treatments," Forest Ecology Management, c. 133, s. 1-2, ss. 71-80, 2000.

[55] T. A. Breland ve S. Hansen, "Nitrogen mineralization and microbial biomass as affected by soil compaction," Soil Biology and Biochemistry, c. 28, s. 4-5, ss. 655-663, 1996.

[56] I. Closa ve N. Goicoechea, "Seasonal dynamics of the physicochemical and biological properties of soils in naturally regenerating, unmanaged and clear-cut beech stands In Northern Spain," European Journal Of Soil Biology, c. 46, s. 3-4, ss. 190-199, 2010.

[57] H. Sever ve E. Makineci, "Ağaçl1-İstanbul maden sahalarında sahil çamı (Pinus pinaster Aiton.) ağaçlandırmalarında bazı ölü örtü ve toprak özellikleri," Türkiye Ormancılık Dergisi,c. 9, s. 2, ss. 136-146, 2008.

[58] E. Görecelioğlu, "Orman ölümü ve İsviçre Ormanlar1,” İstanbul Üniversitesi Orman Fakültesi Dergisi, c. 38, s. 4, ss. 21-31, 1988. 